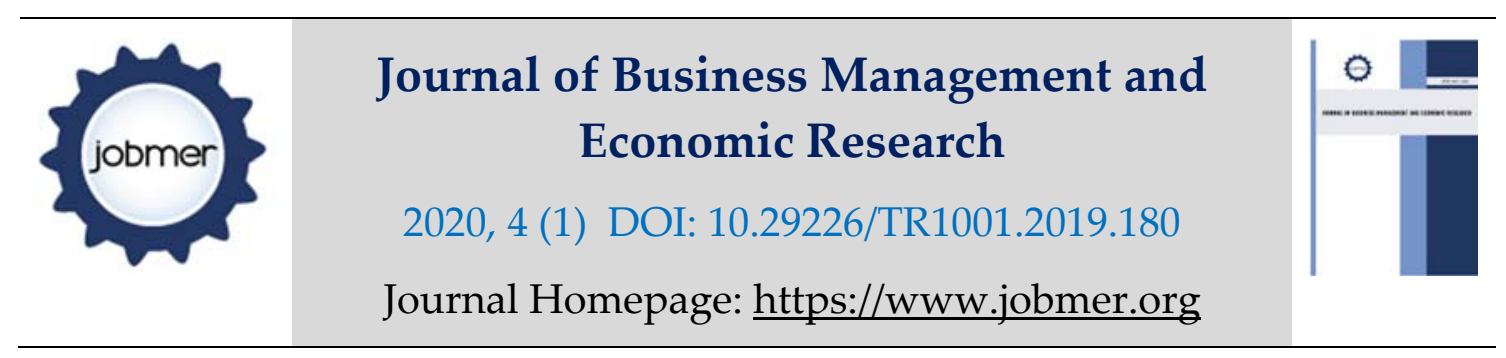

\title{
CHINESE CONSUMERS' CONSPICUOUS PERSPECTIVES: THE CONTEXT OF SMARTPHONE PURCHASE BEHAVIOR
}

\author{
Hiroko Oe \\ (Correspondent author) \\ Bournemouth University \\ 89 Holdenhurst Road \\ Bournemouth \\ BH8 8EB \\ hoe@bournemouth.ac.uk
}

Tel: +44 (0)7852 881051

\section{Yasuyuki Yamaoka}

The Open University of Japan

2-11 Wakaba, Mihama, Chiba city, Japan

yamaoka-y@ouj.ac.jp

\section{Abstract}

This study investigated the key antecedent factors of Chinese consumers attitudes towards smartphones, focusing on the conspicuous value. An analytical framework with three key themes in the smartphone purchasing attributes in relation to the conspicuous attitudes was validated based on Structural Equation Modelling (SEM) using 426 survey data collected in China. It has been found that 'conspicuous value' was the basic perception which has a relation with three key factors, 'fashionableness' and 'innovativeness', and 'instore shopping atmosphere' in smartphone purchasing attributes. This implies that the analytical framework developed from this study is applicable to the research topic as a useful analytical tool kit. From the empirical study based on this framework, it has been found that only 'fashionableness' has the significant impact on their purchase intention, whereas, 'innovativeness' and 'instore shopping atmosphere' did not have a significant impact on their purchase intention of smartphones. Chinese consumer behavior from the cultural context has attracted researchers so far, however, the practical and feasible analytical framework covering the cultural aspect and smartphone attributes has been lacked. This study proposed a practical analytical framework with the Chinese cultural value 'conspicuousness' and focus on the smartphone shopping attributes. Moreover, the empirical research outcome with the survey data based on the proposed framework can provide actionable implications for the relevant marketers and researchers.

Key words: China, conspicuous value, fashionableness, innovativeness, instore shopping atmosphere

Oe, H. \& Yamaoka, Y. (2020). Chinese Consumers' Conspicuous Perspectives: The Context of Smartphone Purchase Behavior. Journal of Business Management and Economic Research (JOBMER), Vol: 4, Issue:1, 1-20. 


\section{Introduction}

\subsection{Background of this study}

With the potential of smartphone market in China, it has acknowledged that it is useful to investigate how firms should cope with drastically changing Chinese smartphone market with changing consumer perceptions and behavior. While the world's economy remains in a state of depression, the potential customer base for smartphones is further revealed through research into the Chinese market, and the underlying data which contributes to its successful marketing strategies. It is common knowledge that Chinese consumer behavior should be analyzed in its cultural context (Hofstede, 2008). The unique nature of the Chinese market that has its origins in Confucian values, its demand for social respect and a particular notion of 'maintaining face' (Mianzi in Mandarin), is intrinsically different from Western social values. Therefore, it is important to understand that Chinese consumers' buying behavior is heavily influenced by these values and winning their preferences in today's competitive market is an essential aspect of a marketing strategy for any enterprise which aims to be successful in the Chinese market (Jin et al., 2010).

\subsection{Research gap}

The concept of this perceived unique value should be investigated in detailed so that the practitioners and researchers can design effective marketing strategies in line with the Chinese consumers' value perceptions, especially in the context of their inclination to bolster their public appearance and status (Vigneron and Johnson, 1999; 2004). There have been a variety of antecedent factors for Chinese consumer purchasing behavior in academic discussions so far, which have acknowledged the necessity of the cultural contextual analysis. For instance, this situation is also the case for the smartphone market. As practitioners need some more robust marketing tool kit because of the huge potential of the Chinese smartphone market and therefore, the contribution of the relevant research has been longed for, the practical and feasible analytical framework has not been agreed on so far. The research gap exists that an analytical framework with the cultural context, focusing on the smartphone attribute is missing which has resulted in the lack of actionable marketing activities in the Chinese smartphone market. 


\subsection{Aim and objectives}

This study aims to explore the Chinese consumers' perceptions towards smartphone purchasing and build a conceptual framework on consumers' purchasing intention. To achieve this aim, four objectives emerged;

- To review relevant literature to develop key themes which represent Chinese consumer behavior towards smartphone purchasing.

- To build a conceptual framework with hypotheses reflecting the developed key themes

- To validate the framework with the collected data from the survey conducted in China based on the Structural Equation Modelling

- To evaluate the results of the research and the framework as a marketing toolkit is proposed

- To conclude and discuss the actionable implications for the marketers and researchers based on the empirical analysis using the proposed framework.

\section{Literature review}

\subsection{Chinese consumer behavior in the smartphone market}

In contemporary society, smartphones have become fully integrated into people's daily lives, with technology an ever-increasing influence on lifestyle (Park, 2019). It is also observed that the smartphone market has developed rapidly responding to the demands of the consumers (Fillion et al., 2016; Liang and Leung, 2018). For businesses, the primary aims of a company include massive profits and meeting the needs of consumers to increase buyer satisfaction customer patronage inevitably plays a vital role in the sales activities. Satisfied and loyal customers contribute to both decreasing costs and increasing profitability (Ehiobuche and Khan, 2012).

Evidently, understanding consumer tendencies and preferences towards goods or services are highly significant in market competition (Fornell, 1992). Investigating and establishing the critical factors in forming an infrastructure of good customer relations and nurturing contentment in the Chinese smartphone market is the primary research theme of this study.

\section{Telecommunication goods and services}

The telecommunications sector plays a vital role in the economic development, due to increased progress in technology and massive competition among the service providers, where smartphones should be one of the key players in leading the telecommunication sector with its 
impact on the businesses in the current digital age (Roos and Edvardsson, 2008). Under this competitive circumstance, service providers are required to give the customers more attractive packages and implement effective marketing strategies to attract potential customers (Akematsu et al., 2012; Bayraktar et al., 2012; Rahul and Majhi, 2014). It is fatal for them to explore different values in a different markets and cultural contexts to retain existing customers and attain new customers based on the sustainable relationships with them (Heinonen et al., 2010). The long-term relations with the customers can be achieved when the resonance can be nurtured in the relationships and it is inevitable for the providers to understand and be ready to launch marketing messages based on a different cultural values to the customers in accordance to each market (Gerpott et al., 2001; Leelakulthanit and Hongcharu, 2012; Rodriguez, 2013).

The tangible attributes (e.g., product appearance, product packaging, instore furnishings) and intangible attributes (e.g., in-store customer services, communication over the counter and brand image) form a basis for the marketing strategy (Ting et al., 2011; Van De Ven et al., 2011; Gobble, 2012; Leelakulthanit and Hongcharu, 2012), but building marketing strategies should be on the basis of understanding of the consumers' cultural values.

\section{Smartphones and Lifestyle}

Chen et al. (2013) discussed that a smartphone is an 'anywhere/anytime compact computer' and 'information/entertainment/infotainment' gadget which has been already a essential tool for the consumers. Ling (2007) suggested that teenagers especially have learned how to coordinate with others by using mobile technologies, exchange their views and opinions, emphasizing that a smartphone is now not only a communication tool but also a communication platform essential to their identity with regards to trends and fashion (Nakamura and Oe, 2009).

\section{Smartphone as a high-end product}

Researchers argue that the social symbol of expensive goods has a significant impact on consumers' purchasing choices (Vickers and Renand, 2003). Especially in China, high-end goods are symbolized as a different set of representations, such as fame, wealth and status; letting consumers have this commodity satisfies not only their material needs but also symbolic demand (Djelic and Ainamo, 1999). It has been discussed that smartphones in China should be analyzed as high-end goods, not only a communication tool (e.g., KPMG, 2012; Marketing China, 2013). Hence, smartphones as higher end gadgets than traditional feature phones might be playing an essential role in the context of social symbolism. 
Individual prosperity and its appearance through consumption is core to the individualism culture (Heaney, Goldsmith and Jusoh, 2005). The immense popularity of Asian consumers for smartphones may be due to taking into account the importance of 'face,' rather than personal preferences (Schütte and Ciarlante, 1999). Conspicuous consumption is common in collectivist cultures and is more about the conformity and acceptance of the community rather than indulgence or self-expression (Phau and Prendergast, 2000). In the Chinese context, this conspicuousness should be one of the impactful underlying value for the Chinese consumer behavior.

\section{Conspicuous value: Cultural orientations and the Chinese market}

Two cultural orientations of individualism and collectivism prompt customers to buy high-end items in different modes (Schütte and Ciarlante, 1998). Researchers believe that today's consumption of high-end goods by Asian consumers emphasizes social meaning conveyed through products. Asian consumers buy high-end goods to ensure public social recognition and observe social norms.

Consumption is considered in traditional Chinese society as a tool to provide high-level demand as an activity in its right (Roy and Eshghi, 2013). Therefore, the Chinese consumer will pay more attention to the social value of the brand than the Western consumer, and actively advance the social value of the brand as Chinese consumers need the social identity (Tse, 1996).

The Chinese emphasis on performing correctly in the same social class, with the appropriate way of consumption is expected to correspond to their behavior and social status. They also need to be distinguished from others in society, which is particularly high in China, for example, the Chinese would like to strengthen social identity with material wealth and brands (Podoshen $e t$ al., 2011). Luxury and high-end goods are often used as tools to increase the distance between different social groups and identify with others with the same social status. In the smartphone context, Chinese consumers are attracted by a more advanced and the most recent model smartphone to satisfy their conspicuous perception. Smartphone purchasing behavior cannot be discussed, therefore, without the conspicuous consumption aspects, as Chadha and Husband (2006) and Chaudhuri and Majumdar (2006) indicated.

\subsection{Key themes underlying conspicuous value in the smartphone context}

Following the discussion above, three key themes are discussed in the context of smartphone purchasing behavior, which will be embedded in the analytical model. The model attained will 
be validated with the primary data to reveal Chinese consumers' attitudes based on the conspicuous value perceptions.

\section{Fashionableness of gadgets}

Lorente (2002) studied the younger generation's preference of fashionableness of mobile phones, focusing on their perspectives on design, and similarly, Noel et al. (2019) indicated that especially the younger generations are attracted by fashionable aspects such as color and the design of gadgets rather than their primary functions. Similar research across various European and Asian countries was conducted by Kasesniemi et al. (2001) and Lorente (2002) which suggest that fashionableness of smartphones should be one of the key elements which attracts the customers. It has been discussed that the success of mobile phones reflects the lifestyle of the young generation (Toufani et al., 2017) and it is suggested that analysis of the impact of the fashionableness of the gadgets should be explored in more depth (Kopoma, 2000; Mäenpää, 2000; Foley et al., 2007; Filieri and Lin, 2017). Nakamura and Oe (2009) analyzed the smartphone's desirability in the context of ostentatiousness; there are clear links between customer satisfaction and the products' fashionable aspects.

\section{Innovativeness}

Research by Holak and Lehmann (1990) showed that usage and a favorable view of a product's predecessor result in consumers' greater willingness to own a new innovative product. It has been indicated that compatibility with the user's lifestyle is affected by the present operating system environment, changes to software interface and the degree of previous experience in using smartphones and other similar gadgets (Sultan, 1999; Kitchen et al., 2015). A conspicuous value could be stimulated by the gadgets' innovative aspects such as a high quality of the snapshots, storage, and application level could be reflecting consumers' conspicuous attitudes (Noel et al., 2019), who also suggested this inclination to the innovative aspects can be accelerated in line with the higher social status.

Convergent products have received increasing amounts of attention recently (Gill, 2008; Gill and Lei, 2009; Han et al., 2009; Lee et al., 2013). Consumers' perceptions, the innovative technological aspects of gadgets should be one of the components of the conspicuous value. Smartphone purchasing behavior should, therefore, be analyzed with regards to those innovative aspects of the products as one of the constituents of the conspicuousness (Podoshen et al., 2011; Komatsu, 2004). Innovative functionality is one of the factors that affect customers' purchase intention of smartphones. 


\section{Instore shopping atmosphere}

Research has debated that shopping atmosphere influences business performance and customer loyalty (Demirci Orel and Kara, 2014; Garga and Bambale, 2016; van Lierop and El-Geneidy, 2016). For instance, as Kemp et al., (2019) discussed, happy customers will get back to the store which supports the sustainable businesses for the businesses (e.g., $\mathrm{Hu}$ and Jasper, 2006; Maruyama and $\mathrm{Wu}, 2014)$. It has been discussed with the evidence from the empirical studies that customers become more loyal to the goods and services with the good shopping atmosphere, which can enhance customer relations with the suppliers (Ogle et al., 2004; Pan and Zinkhan, 2006; Garga and Bambale, 2016; Terblanche, 2018).

More specifically, instore shopping atmosphere can be analyzed in the context of the conspicuous value of consumers. It is because consumers appreciate the store stuff attitudes towards them while they are shopping. Being Treated nicely instore should be one of the essential factors to retain loyal customers (Kim et al., 2016). Customers' positive attitudes towards goods and services are changeable; the most important thing is to learn how to maintain a good relationship between customers and the organization (Hill, 2000; Haryono and Sihombing, 2018). Customers appreciate the warmth attitudes with a comfortable touch treating them as if they are VIPs, and also they appreciate the shop decoration and physical atmosphere which overall makes the customer to feel they are special to the shop and the relevant brands (Li et al., 2015; Baek et al., 2018).

In the Chinese context, the concept of 'Saving face=mianzi' could also be important element for the marketers to consider: Mianzi is one of the underpinning motives for Chinese consumers to buy products, especially something high-end, luxury or expensive (Filieri et al., 2018; Huang and Wang, 2018). Chinese consumers view the external social needs (e.g., mianzi, status) as more important than internal individual needs (Wong and Ahuvia, 1998). Ho (1976) discussed the concept of 'mianzi' plays an important role and expresses both personal and non-personal characteristics (e.g., wealth, authority) when consumers were served by shop staff. In the smartphone purchasing scenario, the 'mianzi' should also be considered in the context of instore shopping atmosphere, as Chinese consumers perceive the in-store shopping atmosphere as one of the key factors to be attracted by the shops whose staff treat them as important customers and keep the customers' 'mianzi' in front of others in the public space. 


\subsection{Hypotheses}

From the literature review, Chinese consumer behavior towards smartphone can be analyzed based on conspicuous value as the critical antecedent factor underpinning their perception which could be explained by three factors, fashionableness, innovativeness, and instore shopping atmosphere. Moreover, our literature review suggests that these three sub factors could have an impact on Chinese consumers' purchase intention of smartphones.

This study aims to reveal potential relationships based on a quantitative method for testing the following hypotheses. Table 1 shows the hypotheses built based on the literature review with the relevant supportive academic discussions.

Table 1. Hypotheses of this study

\begin{tabular}{|c|c|c|}
\hline $\begin{array}{l}\text { Hypothesis } \\
\text { number }\end{array}$ & Hypothesis & Supportive acdemic discussions \\
\hline $\mathrm{H} 1$ & $\begin{array}{l}\text { Conspicuous consumer value has a positive relation } \\
\text { with 'fashionableness' of smartphones }\end{array}$ & $\begin{array}{l}\text { Hirsjärvi et al., 1982; Drotner, 2000; Kasesniemi et } \\
\text { al., 2001; Lorente, 2002; Komatsu, 2004; Ito, 2005; } \\
\text { Foley et al., 2007; Noel et al., } 2018\end{array}$ \\
\hline $\mathrm{H} 2$ & $\begin{array}{l}\text { Conspicuous consumer value has a positive relation } \\
\text { with 'innovativeness' of smartphones }\end{array}$ & $\begin{array}{l}\text { Holak and Lehmann, 1990; Sultan, 1999; Olsen, } \\
\text { 2002; Kotler and Keller, 2009; Podoshen, 2011; } \\
\text { Noel et al., 2018; Vonortas, } 2018\end{array}$ \\
\hline H3 & $\begin{array}{l}\text { Conspicuous consumer value has a positive relation } \\
\text { with 'instore shopping atmosphere' }\end{array}$ & $\begin{array}{l}\text { Bitner and Hubbert, 1994; Jones et al., 2000; } \\
\text { Bodet, 2008; Li et al., 2015; Kim et al., 2016; Baek } \\
\text { et al., 2018; Haryono and Sihombing, 2018; } \\
\text { Terblanche, 2018; Kemp et al., } 2019\end{array}$ \\
\hline $\mathrm{H} 4 \mathrm{a}$ & $\begin{array}{l}\text { The factor 'fashionableness' has a positive impact } \\
\text { on purchase intention of smartphones }\end{array}$ & $\begin{array}{l}\text { Holak and Lehmann, 1990; Chadha and Husband, } \\
\text { 2006; Filieri, 2017; Hsiao, 2017; Toufani, } 2017\end{array}$ \\
\hline $\mathrm{H} 4 \mathrm{~b}$ & $\begin{array}{l}\text { The factor 'innovativeness' has a positive impact } \\
\text { on purchase intention of smartphones }\end{array}$ & $\begin{array}{l}\text { Holak and Lehmann, 1990; Sultan, 1999; Olsen, } \\
\text { 2002; Kotler and Keller, 2009; Podoshen, 2011; } \\
\text { Noel et al., 2018; Vonortas, 2018; Hong, 2017; } \\
\text { Kim et al., 2018; Reddy et al., } 2018\end{array}$ \\
\hline $\mathrm{H} 4 \mathrm{c}$ & $\begin{array}{l}\text { The factor 'instore shopping atmosphere' has a } \\
\text { positive impact on purchase intention of } \\
\text { smartphones }\end{array}$ & $\begin{array}{l}\text { Bitner and Hubbert, 1994; Jones et al., 2000; } \\
\text { Olsen, 2002; Bodet, 2008; Çifci, et al., 2016; Paul } \\
\text { et al., 2016; Liu, 2017; Manner, } 2018\end{array}$ \\
\hline
\end{tabular}

As a summary of this section, Figure 1 shows the conceptual framework of this study with the hypotheses. 


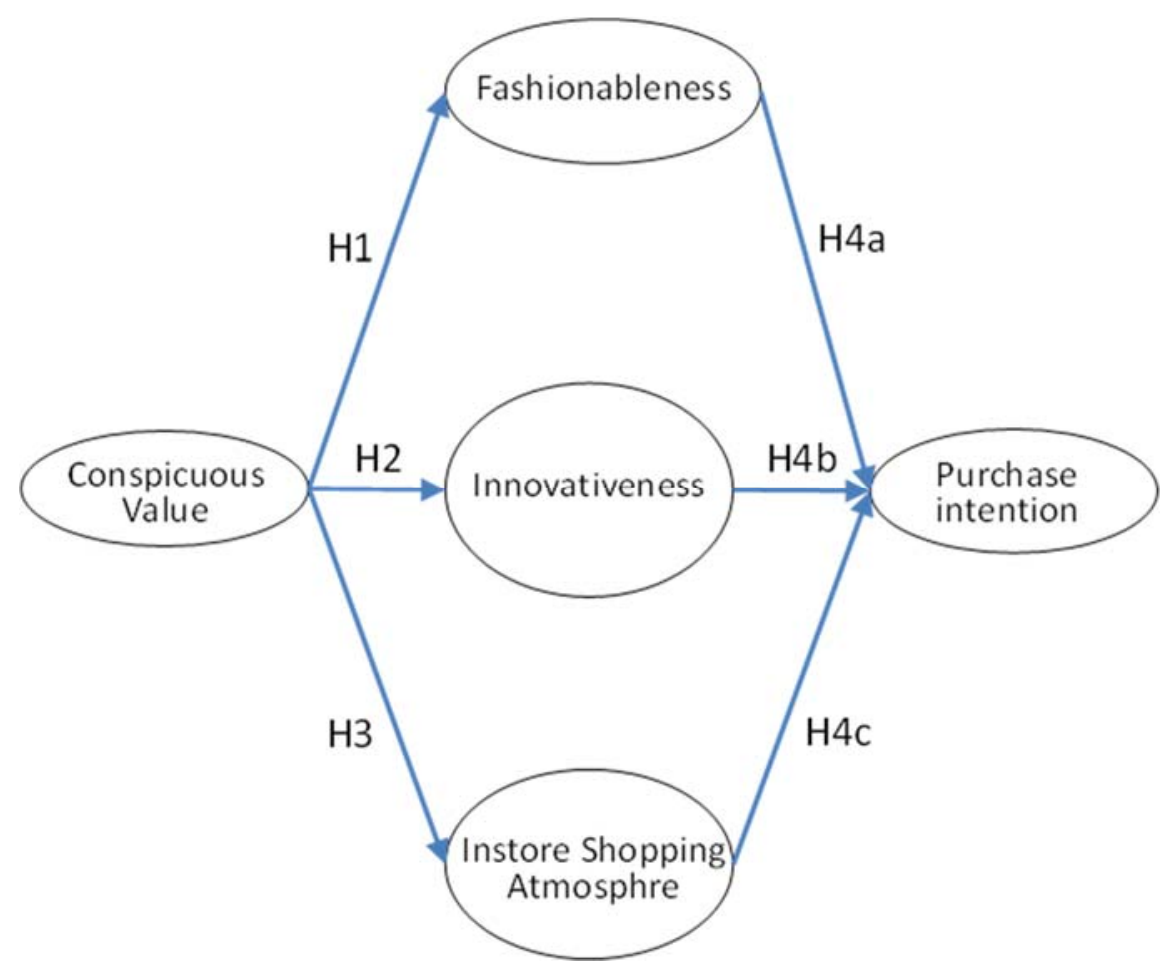

Figure 1. Conceptual framework and hypotheses

\section{Methodology}

\subsection{Research Approach and Methodology}

This study uses the deductive approach as the aim of this study is to test and validate a conceptual model with measurements with data collected from consumers in the Chinese market. Data is gathered through the online survey, and the data set is going to be analyzed with SPSS ver. 23. A quantitative method is applied to test predetermined hypotheses that are deduced based on existing theory (Weathington et al., 2012).

It is believed that the most suitable purpose of this research is descriptive because the authors will describe the Chinese consumer's behavior (Ghauri and Grohauug, 2005).

\subsection{Data Collection}

As Weathington et al. (2012) debated, surveys attempt to gather information from an entire group which is usually a sample (Swetnam, 2004). Thirty items were prepared for the questionnaire, with some modification of wording and format following a pilot test with 50 informants in advance. The survey was conducted by an internet-based survey website, Survey Monkey, to collect primary data for the analysis. 
The questions and corresponding options used in this research have been carefully measured and chosen, focusing on which related factors affect customer loyalty and how smartphone firms attract customers in the Chinese smartphone market. Based on the research aim and associated hypotheses, the questionnaire consists of questions designed to assess the factors developed in the hypotheses: conspicuousness, fashionableness, innovativeness, instore shopping atmosphere and purchase intention of smartphones.

426 responses were collected, which represent a spectrum of ages and gender in China. The questions can be divided into two parts, including general information and more detailed responses. For data analysis, SPSS version 23 was used.

\section{Findings and analysis}

\subsection{Data}

Table 2 shows the outline of the respondents' demographic profile.

Table 2. Profile of the respondents

\begin{tabular}{|c|c|c|c|}
\hline Age & Count & $\%$ & Cumulative $\%$ \\
\hline$\overline{\mathrm{U} 18}$ & 34 & $8.00 \%$ & $\overline{8}$ \\
\hline $18-24$ & 196 & $46.00 \%$ & 54 \\
\hline $25-30$ & 84 & $19.70 \%$ & 73.7 \\
\hline 30 's & 43 & $10.10 \%$ & 83.8 \\
\hline 40 's & 43 & $10.10 \%$ & 93.9 \\
\hline $50 \mathrm{~s}$ & 21 & $4.90 \%$ & 98.8 \\
\hline 60 's & 5 & $1.20 \%$ & 100 \\
\hline Total & 426 & $100.00 \%$ & \\
\hline Gender & Count & $\%$ & Cumulative $\%$ \\
\hline Male & 205 & $48.10 \%$ & 48.1 \\
\hline Female & 220 & $51.60 \%$ & 99.8 \\
\hline No answer & 1 & $0.20 \%$ & 100 \\
\hline Total & 426 & $100.00 \%$ & \\
\hline Social class & Count & $\%$ & Cumulative \% \\
\hline Unemployed & 41 & $9.60 \%$ & 9.6 \\
\hline Student & 175 & $41.10 \%$ & 50.7 \\
\hline Bule color & 62 & $14.60 \%$ & 65.3 \\
\hline White color & 147 & $34.50 \%$ & 99.8 \\
\hline Other & 1 & $0.20 \%$ & 100 \\
\hline Total & 426 & $100.00 \%$ & \\
\hline Economic background & Count & $\%$ & Cumulative \% \\
\hline$\overline{U 500}$ & 60 & $14.10 \%$ & 14.1 \\
\hline $501-1000$ & 92 & $21.60 \%$ & 35.7 \\
\hline $1001-2000$ & 56 & $13.10 \%$ & 48.8 \\
\hline $2001-3000$ & 52 & $12.20 \%$ & 61 \\
\hline $3001-4000$ & 66 & $15.50 \%$ & 76.5 \\
\hline $4001-5000$ & 53 & $12.40 \%$ & 89 \\
\hline $5001-6000$ & 24 & $5.60 \%$ & 94.6 \\
\hline $6001-8000$ & 16 & $3.80 \%$ & 98.4 \\
\hline O8001 & 7 & $1.60 \%$ & 100 \\
\hline Total & 426 & $100.00 \%$ & \\
\hline
\end{tabular}




\subsection{Reliability of the prepared variables for the Semi Structural Modelling (SEM) analysis}

We conducted a descriptive analysis as a preliminary preparation for the hypotheses testing. Table 3 shows the descriptive statistics of observed variables for the 'conspicuousness,' ant three key themes, 'fashionableness,' 'innovativeness,' and 'instore shopping atmosphere.' As three key themes which should represent 'conspicuousness,' it is also essential to validate the reliability of these three factors.

According to Hair et al. (2010), the set of variables with Cronbach's alpha higher than 0.600 can be acknowledged to be reliable and compatible with the analysis. Therefore, the Cronbach's alpha test was applied to the relevant variables which consist of the three key themes, the results are summarized in Table 3. From this process, it has been found that prepared nine variables are statistically reliable for the hypotheses testing which will be conducted based on the SEM analysis.

Table 3. Observed variables representing consumers' perceptions

\begin{tabular}{clrrrc}
\hline Latent factors & \multicolumn{1}{c}{ Compornents } & Count & Mean & Std. Dev. & Alpha \\
\hline \multirow{2}{*}{ Conspicuous value } & Showing-off of possession & 426 & 3.75 & 0.80 & 0.601 \\
& Expensiveness & 426 & 3.60 & 0.81 & 0.84 \\
\hline \multirow{2}{*}{ Fashionableness } & Suitable for lifestyle & 426 & 3.59 & 0.778 \\
& Fashionable gadgets preference & 426 & 3.48 & 0.87 & \\
\hline \multirow{2}{*}{ Innovatuveness } & Product feature & 426 & 3.78 & 0.77 & 0.701 \\
& Innovative Design & 426 & 3.54 & 0.80 & \\
\hline \multirow{2}{*}{ Instore shopping } & Fancy and posh atmosphere & 426 & 3.55 & 0.80 & \\
atmosphere & Customer service quality & 426 & 3.59 & 0.81 & 0.858 \\
& After-sales support & 426 & 3.52 & 0.79 & \\
\hline \multirow{2}{*}{ Purachase intention } & Purachase intention & 426 & 3.47 & 0.82 & \multirow{2}{*}{0.684} \\
& Recommend to others & 426 & 3.32 & 0.83 & \\
\hline
\end{tabular}

\section{SEM Analysis}

SEM is conducted to test the hypotheses, focusing on the paths that influence customers' purchase intention. Figure 2 demonstrates the outcome of SEM with statistical coefficients with the significant relations among the relevant factors generated from the factor analysis. 


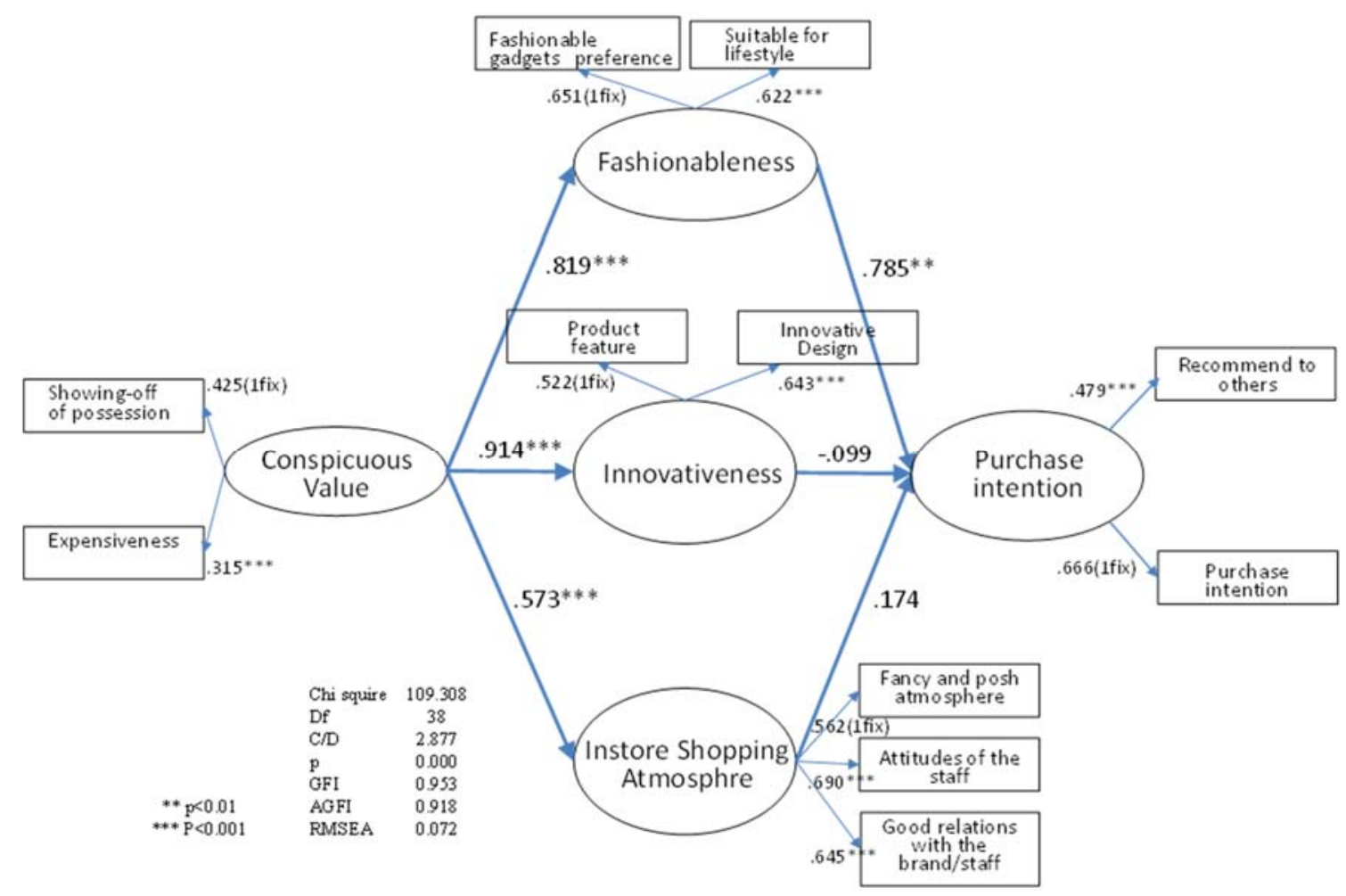

Figure 2. Result of SEM analysis

SEM was used to analyze the data, and the measurement model had acceptability to fit the measures. Specifically, the fit measures for the research model included a $\chi 2 /$ degrees of freedom ration of 2.877 ( $\chi 2=109.308, \mathrm{df}=38$ ); it met the recommended level of 5.0 (Hair et al., 1998). As other results of fitting tests, GFI (0.953), AGFI (0.918) are high above the recommended level of $>0.90$, whereas RMSEA (0.072) also met the recommended level <0.10 (Hair et al., 1998). Thus, the results of the substantive model are going to be examined in the next step. 
Table 4. Path coefficients

\begin{tabular}{|c|c|c|c|c|}
\hline To & & From & $\begin{array}{l}\text { Staderdized path } \\
\text { coefficient }\end{array}$ & $\mathrm{p}$ \\
\hline Inovativeness & $<---$ & Conspicuous value & 0.914 & $* * *$ \\
\hline Instore shopping atmosphere & $<---$ & Conspicuous value & 0.573 & $* * *$ \\
\hline Fashionableness & $<---$ & Conspicuous value & 0.819 & $* * *$ \\
\hline Showing-off if ois sessuion & $<---$ & Conspicuous value & 0.425 & 1 fix \\
\hline Expensiveness & $<---$ & Conspicuous value & 0.315 & $* * *$ \\
\hline Purchase intention & $<---$ & Fashionableness & 0.785 & $* *$ \\
\hline Fashionable gadgets preference & $<---$ & Fashionableness & 0.651 & 1 fix \\
\hline Suitable for lifestyle & $<---$ & Fashionableness & 0.622 & $* * *$ \\
\hline Purchase intention & $<---$ & Inovativeness & -0.099 & 0.067 \\
\hline Pruduct feature & $<---$ & Inovativeness & 0.522 & 1 fix \\
\hline Innovative designe & $<---$ & Inovativeness & 0.643 & $* * *$ \\
\hline Purchase intention & $<---$ & Instore shopping atmosphere & 0.174 & 0.110 \\
\hline Fancy and posh atmosphere & $<---$ & Instore shopping atmosphere & 0.562 & 1 fix \\
\hline Attitudes of the staff & $<---$ & Instore shopping atmosphere & 0.690 & $* * *$ \\
\hline $\begin{array}{l}\text { Good relations with the } \\
\text { brand/staff }\end{array}$ & $<---$ & Instore shopping atmosphere & 0.645 & $* * *$ \\
\hline Recommend to others & $<---$ & Purchase intention & 0.479 & $* * *$ \\
\hline \multirow[t]{2}{*}{ Loyal to the brand } & $<--$ & Purchase intention & 0.666 & 1 fix \\
\hline & & & $\begin{array}{r}* \\
* * \\
* * *\end{array}$ & $\begin{array}{l}<0.05 \\
<0.01 \\
<0.001\end{array}$ \\
\hline
\end{tabular}

\section{Hypotheses Testing}

Figure 2 indicating that this model is reliable, with the coefficients from conspicuous consumption to three latent factors as follows: fashionableness $=0.819(\mathrm{p}<0.001)$, innovative product features $=0.914(\mathrm{p}<0.001)$, service quality $=0.573(\mathrm{p}<0.001)$. Out of three latent variables, the innovative product features and fashionableness factors show bigger coefficients from conspicuous consumption compared with the instore shopping atmosphere. With differences between these three, the conspicuous consumption factor is significantly leading to all three variables. Hence Hypotheses 1, 2 and 3 are all supported. 
Out of the Hypotheses 4a, $4 \mathrm{~b}$ and $4 \mathrm{c}$, only H4a (fashionableness) is supported $(0.785, \mathrm{p}<0.01)$ which indicates that fashionableness only has a significant impact on the Chinese consumers' purchase intention of smartphones. On the other hand, contradictory to the previous researchers' findings about service quality (Bitner and Hubbert, 1994; Jones et al., 2000; Bodet, 2008; Olsen, 2002), H4c (instore shopping atmosphere) was rejected $(0.174, \mathrm{p}=0.110)$, whereas H4b (innovativeness) was also rejected with no significance of the path coefficients $(-0.099, \mathrm{p}=0.067)$. Table 4 shows the detailed results of the relationships among the factors and observed variables. Table 5 summarises the results of the hypotheses testing.

Table 5. Summary of the hypotheses testing

\begin{tabular}{|c|c|c|}
\hline $\begin{array}{l}\text { Hypothesis } \\
\text { number }\end{array}$ & Hypothesis & Result \\
\hline H1 & $\begin{array}{l}\text { Conspicuous consumer value has a positive relation with } \\
\text { 'fashionableness' of smartphones }\end{array}$ & Supported \\
\hline $\mathrm{H} 2$ & $\begin{array}{l}\text { Conspicuous consumer value has a positive relation with } \\
\text { 'innovativeness' of smartphones }\end{array}$ & Supported \\
\hline $\mathrm{H} 3$ & $\begin{array}{l}\text { Conspicuous consumer value has a positive relation with } \\
\text { 'instore shopping atmosphere' }\end{array}$ & Supported \\
\hline $\mathrm{H} 4 \mathrm{a}$ & $\begin{array}{l}\text { The factor 'fashionableness' has a positive impact on } \\
\text { purchase intention of smartphones }\end{array}$ & Supported \\
\hline $\mathrm{H} 4 \mathrm{~b}$ & $\begin{array}{l}\text { The factor 'innovativeness' has a positive impact on } \\
\text { purchase intention of smartphones }\end{array}$ & Not Supported \\
\hline $\mathrm{H} 4 \mathrm{c}$ & $\begin{array}{l}\text { The factor 'instore shopping atmosphere' has a positive } \\
\text { impact on purchase intention of smartphones }\end{array}$ & Not Supported \\
\hline
\end{tabular}

\section{Conclusion}

\subsection{Overall findings}

The results of the analysis show that conspicuous consuming attitudes exist as a basis for Chinese consumers' perceptions which leads to three aspects of smartphone shopping attributes: fashionableness, innovativeness, and instore shopping atmosphere. Their conspicuous value was found to have a significant impact on their evaluation towards three attributes of smartphone purchasing. However, among the three paths from these factors, only fashionableness has a 
significant impact, neither innovativeness nor instore shopping atmosphere has the impact on consumers' purchase intention of smartphones.

From the outcome of this study, the factor of conspicuous consumption was found to be a base for the consumers' attitudes towards smartphone purchasing. The fact that the proposed analytical framework in the context of smartphone purchasing is approved indicates that Chinese consumers' behavior is based on the unique cultural element of conspicuous value.

In this study, the authors break down this conspicuous value into three pathways; fashionableness, innovativeness, and instore shopping atmosphere. By this approach, only the factor of fashionableness has a significant impact on consumers' purchase intention, whereas innovativeness and instore shopping atmosphere are not perceived to be influential for consumers' purchase intention. Chinese conspicuousness has been studied by empirically so far, but one of the contributions from this study should be the practical analytical framework is proposed for the marketers and researchers for further investigation to develop actionable implications for the relevant businesses.

The approach conducted in this study which factorized the intangible value into tangible elements in the smartphone shopping attributes enables the practitioners and researchers to implement an actionable strategy to attract consumers.

\subsection{Limitations}

Firstly, the data profile indicates that $66 \%$ of the data set is concentrated for the age band of 18 $24(46.0 \%)$ and $25-30(19.7 \%)$, who are categorized as the 'digital natives', as the main theme of this study focuses on Chinese consumers' attitudes towards smartphones, the targeted samples were the cohort who are the most familiar the technological gadgets (McMahon and Pospisil, 2005; Hutton and Fosdick, 2011). To attain more robust outcome with implications for the smartphone market, the well-balanced dataset representing the whole population should be needed. Secondly, it is required to elaborate the proposed models, investigating into the broken down the conspicuous value in the smartphone purchasing. The study pointed out only three key themes as the factors encompassing the conspicuous value in the model; this model with three bottom line factors should be investigated with some bigger dataset to generate actionable implications for the researchers and marketers. The dimensions and measurements of the analytical model should be explored and validated in further research. 


\subsection{Further research opportunities}

To be able to develop some more robust and actionable implications for the marketers and researchers, it is needed to get a larger dataset to deepen the analysis and propose appropriate measurements for the field of study. In doing so, it is required to investigate the impact of service quality and innovative attributes of smartphones further. It is also required to explore the relations with Chinese consumers' conspicuous value as the basis for their purchasing intention of smartphones.

The exploration into the Chinese market and Chinese consumers' behavior in the technologybased goods market should cast both academic and practical implications to the existing and potential businesses who aim to penetrate the vast market with different values and cultural backgrounds. In this regard, it is essential for the researchers to investigate the cultural impact on consumer behavior in the divers of markets. Research into the social and cultural context should be more closely investigated and could contribute to building an effective marketing strategy in the real economy, which this study aimed and objected.

\section{Acknowledgement}

The authors appreciate the dedicated support from Miss Rui Zhang who helped us in collecting data in China. Without her contribution, we could not have completed this research work.

\section{References}

Akematsu, Y., Shinohara, S. and Tsuji, M. (2012), Empirical analysis of factors promoting the Japanese 3G mobile phone, Telecommunications Policy, 36 (3), 175-186.

Bayraktar, E., Tatoglu, E., Turkyilmaz, A., Delen, D. and Zaim, S. (2012), Measuring the efficiency of customer satisfaction and loyalty for mobile phone brands with DEA, Expert Systems With Applications, 39, 99-106.

Baek, E., Choo, H. J., and Lee, S. H. M. (2018), Using warmth as the visual design of a store: Intimacy, relational needs, and approach intentions, Journal of Business Research, 88, 91-101.

Berry, L.L., Parasuraman, A. and Zeithaml, V.A. (1994), Improved service quality in America: Lessons learned, Academy of Management Executive. 8 (2), 32-52.

Bitner, M. J. and Hubbert, A. R. (1994), Encounter Satisfaction versus Overall Satisfaction versus Quality, Service Quality New Directions in Theory and Practices, London: Sage Publications. 7295.

Bodet, G. (2008), Customer satisfaction and loyalty in service: Two concepts, four constructs, several relationships, Journal of Retailing and Consumer Services, 15, 156-163.

Chadha, R. and Husband, P. (2006), The cult of luxury brand: Inside Asia's love affair with luxury, London: Nicholas Brealey International. 
Chaudhuri, H. R. and Majumdar, S. (2006), Of Diamonds and Desires: Understanding Conspicuous Consumption from a Contemporary Marketing Perspective, Journal of Marketing Science Review, 10 (8), 1-18.

Chen, S.-C. (2012), The customer satisfaction-loyalty relation in an interactive e-service setting: The mediators, Journal of Retailing and Consumer Services, 19, 202-210.

Chen, H.,Liu, F. and Dai, T. (2013), Chinese Consumers' Perceptions toward Smartphone and marketing Communication on Smartphone, International Journal of Mobile Marketing, 1, 38-45.

Demirci Orel, F. and Kara, A. (2014), Supermarket self-checkout service quality, customer satisfaction, and loyalty: Empirical evidence from an emerging market, Journal of Retailing and Consumer Services. 21, 118-129.

Ehiobuche, C. and Khan, F. (2012), Customer loyalty paradigms, Franklin Business \& Law Journal, 83-97.

Filieri, R., and Lin, Z. (2017), The role of aesthetic, cultural, utilitarian and branding factors in young Chinese consumers' repurchase intention of smartphone brands, Computers in Human Behavior, 67, 139-150.

Filieri, R., Lin, Z., D’Antone, S., \& Chatzopoulou, E. (2018), A cultural approach to brand equity: the role of brand mianzi and brand popularity in China, Journal of Brand Management, 1-19.

Fillion, G., Mvuyekure, P. D., Nguejo, A. N. and Ekionea, J. P. B. (2016), Mobile telephony: What are the influencing factors of using a mobile phone in Cameroon?, Academy of Information $\mathcal{E}$ Management Sciences Journal, 19 (1), 94-119.

Foley, C., Holzman, C., and Wearing, S. (2007), Moving beyond conspicuous leisure consumption: Adolescent women, mobile phones and public space, Leisure Studies, 26 (2), 179-192.

Fornell, C. (1992), A national customer satisfaction barometer: The Swedish experience, Journal of Marketing, 56, 6-21.

Garga, E. and Bambale, A. J. A. (2016), The Impact of Service Quality on Customer Patronage: Mediating Effects of Switching Cost and Customer Satisfaction, International Journal of Global Business, 9 (1), 39-58.

Ghauri, P. and Grohauug, K. (2005), Research Methods in Business Studies. 3rd edition, Edinburgh: Pearson Education Limited.

Gerpott, T. J., Rams, W. and Schindler, A. (2001), Customer retention, loyalty and satisfaction in the German mobile cellular telecommunications market, Telecommunications Policy, 25, 249269.

Gill, T. (2008), Convergent products: What functionalities add more value to the base?, Journal of Marketing. 72 (2), 46-62.

Gill, T. and J. Lei. (2009), Convergence in the high-technology consumer markets: Not all brands gain equally from adding new functionalities to products, Marketing Letters, 20 (1), 91-103.

Hair, J. F., Black, W. C., Babin, B. J. and Anderson, R. E. (2010), Multivariate Data Analysis: A Global Perspective, 7 th edition. New Jersey: Pearson.

Haryono, R. I., \& Sihombing, S. O. (2018), The Effects of Store Environment and Merchandise to Customer Responses: an Empirical Study, Jurnal Dinamika Manajemen, 9 (1), 33-43. 
Heinonen, K., Strandvik, T., Mickelsson, KL. Edvardsson, B., Sundstron, E. and Andersson, P. (2010), A customer-dominant logic of service", Journal of Service Management, 21 (4), 531-548.

Ho, D. (1976), On the concept of face, American Journal of Sociology, 81 (4), 867-884.

Holak, S. L. and Lehmann, D. R. (1990), Purchase intentions and the dimensions of innovation: an exploratory model, Journal of product innovation management, 7 (1), 59-73.

Hong, J. C., Lin, P. H., and Hsieh, P. C. (2017), The effect of consumer innovativeness on perceived value and continuance intention to use smartwatch, Computers in Human Behavior, 67, 264272.

Hsiao, K. L. (2017), What drives smartwatch adoption intention? Comparing Apple and nonApple watches, Library Hi Tech, 35 (1), 186-206.

$\mathrm{Hu}, \mathrm{H}$. and Jasper, C. R. (2006), Social cues in the store environment and their impact on store image, International Journal of Retail \& Distribution Management, 34 (1), 25-48.

Huang, Z., \& Wang, C. L. (2018), Conspicuous consumption in emerging market: The case of Chinese migrant workers, Journal of Business Research, 86, 366-373.

Hutton, G. and Fosdick, M. (2011), The Globalization of Social Media: Consumer Relationships with Brands Evolve in the Digital Space, Journal of Advertising Research, 51 (4), 564-570.

Jin, C., Furukawa, I. and Shi, Z. (2010), Mianzi and consumer behavior in the Chinese market : a literature review, Economics Review, Seijo University, 188, 159-175.

Jones, M. A. and Suh, J. (2000), Transaction-specific satisfaction and overall satisfaction: an empirical analysis, Journal of Services Marketing, 14, 147-160.

Kasesniemi, E. and Rautiainen, P. (2001), Mobile Culture of Children and Teenagers in Finland. In Katz J., Aakhus M. (eds) Perpetual Contact: Mobile Communication, Private Talk, Public Performance, Cambridge: Cambridge University Press, Painossa.

Kemp, E. A., Williams, K., Min, D. J., and Chen, H. (2019), Happy feelings: examining music in the service environment, International Hospitality Review, ahead of printing.

Kim, S., Katsumata, S., and Akiike, A. (2018), Dynamic Change in the Importance of Innovation in the Smartphone Market, In ISPIM Innovation Symposium, The International Society for Professional Innovation Management (ISPIM), 1-14.

Kim, S., Park, G., Lee, Y., and Choi, S. (2016), Customer emotions and their triggers in luxury retail: Understanding the effects of customer emotions before and after entering a luxury shop, Journal of Business Research, 69 (12), 5809-5818.

Kitchen, P. J., Martin, R. and Che-Ha, N. (2015), Long term evolution mobile services and intention to adopt: a Malaysian perspective, Journal of Strategic Marketing, 23 (7), 643-654.

Komatsu, A. (2004), Consumer Choice and Socio-psychological Evaluation of Product Style, The Bulletin of Japan Society for Science of Design, 51 (4), 55-64.

KPMG (2012), Global Reach of Chinese Luxury: A KPMG study, available at: kpmg.com/cn (accessed 26 October 2019).

Lee, H., Lee, Y. and Yoo, D. (2000), The determinants of perceived service quality and its relationship with satisfaction, Journal of Services Marketing, 14 (3), 217-231.

Lee, S., Lee, J.-H. and Garrett, T. C. (2013), A study of the attitude toward convergent products: A focus on the consumer perception of functionalities a study of the attitude toward 
convergent products: A focus on the consumer perception of functionalities, Journal of Product Innovation Management, 30 (1), 123-135.

Leelakulthanit, O. and Hongcharu, B. (2012), Factors Influencing Smartphone Repurchase, Journal of Business \& Economics Research, 10 (11), 623-628.

Li, Y., Fu, H., and Huang, S. S. (2015), Does conspicuous decoration style influence customer's intention to purchase? The moderating effect of CSR practices, International Journal of Hospitality Management, 51, 19-29.

Liang, J., \& Leung, L. (2018), Comparing Smartphone Addiction: The Prevalence, Predictors, and Negative Consequences in Hong Kong and Mainland China, The Journal of Social Media in Society, 7 (2), 297-322.

Liu, D., and Guo, X. (2017), Can trust and social benefit really help? Empirical examination of purchase intentions for wearable devices, Information Development, 33 (1), 43-56.

Lorente, S. (2002), Youth and Mobile Telephones: More than a Fashion, REVISTA DE ESTUDIOS DE JUVENTUD, 57, 9-24.

Mäenpää, P. (2000), Digitaalisen arjen ituja. Kännykkä ja urbaani elämäntapa (Seeds of digital everyday life: The mobile phone and the urban way of life), In Tommi Hoikkala y J. P. Roos (Eds) 2000luvun elämä. Sosiologisia teorioita vuosituhannen vaihteesta (Life in 2000. Sociological theories from the turn of the millennium). Tampere: Gaudeamus.

Marketing China (2013), China, a Booming Market for Luxury, http://marketingtochina.com/china-a-booming-market-for-luxury/ (accessed 26 October 2019).

Maruyama, M. and Wu, L. (2014), Multiple store patronage: The effects of store characteristics, Journal of Retailing and Consumer Services, 21 (4), 601-609.

McMahon, M. and Pospisil, R. (2005), Laptops for a digital lifestyle: Millennial students and wireless mobile technologies, Balance, Fidelity, Mobility: maintaining the momentum, 2, 421-431.

Nakamura, T. and Oe, H. (2009), Looking at Keitai (MobilePhone) Displays as a Form of NonVerbal Behavior in Public Spaces, Journal of Infosocionomics Society, 4 (1), 27-37.

Noel, L., Sovacool, B. K., Kester, J., \& de Rubens, G. Z. (2019). Conspicuous diffusion: Theorizing how status drives innovation in electric mobility. Environmental Innovation and Societal Transitions, 31, 154-169.

Ogle, J. P., Hyllegard, K. H. and Dunbar, B. H. (2004), Predicting Patronage Behaviors in a Sustainable Retail Environment: Adding Retail Characteristics and Consumer Lifestyle Orientation to the Belief-Attitude-Behavior Intention Model, Environment \& Behavior, 36 (5), 717-741.

Pan, Y. and Zinkhan, G. M., (2006), Determinants of retail patronage: A meta-analytical perspective, Journal of Retailing, 82, 229-243.

Park, C. S. (2019), Examination of smartphone dependence: Functionally and existentially dependent behavior on the smartphone, Computers in Human Behavior, 93, 123-128.

Parasuraman, A., Zeithaml, V. A. and Berry, L. L. (1985), A conceptual model of service quality and its implications for future research, Journal of Marketing, 49, 41-50.

Paul, J., Sankaranarayanan, K. G., and Mekoth, N. (2016), Consumer satisfaction in retail stores: Theory and implications, International Journal of Consumer Studies, 40 (6), 635-642. 
Podoshen, J. S., Lu, L. and Junfeng, Z. (2011), Materialism and conspicuous consumption in China: a cross-cultural examination, International Journal of Consumer Studies, 35 (1), 17-25.

Rahul, T. and Majhi, R. (2014), An adaptive nonlinear approach for estimation of consumer satisfaction and loyalty in mobile phone sector of India, Journal of Retailing and Consumer Services. 21, 570-580.

Reddy, S. R. N., Kaur, J., Chande, S., and Challa, R. K. (2018), My smartphone kit: Design and development of an integrated platform for innovation and product design in engineering education", Computer Applications in Engineering Education, 26 (3), 642-654.

Rodriguez, A. (2013), Smartphones, PC World, 31 (2), 69-70.

Roos, I. and Edvardsson, B. (2008), Customer-support service in the relationship perspective, Managing Service Quality, 18 (1), 87-107.

Roy, S. K. and Eshghi, A. (2013), Does relationship quality matter in service relationships?, Journal of Strategic Marketing, 21 (5), 443-458.

Sultan, F. (1999), Consumer preference for forthcoming innovations, Journal of Consumer Marketing. 16, 24-41.

Swetnam, D. (2004), Writing your Dissertation. 3rd edition, Oxford: Derek Swetnam.

Terblanche, N. S. (2018), Revisiting the supermarket in-store customer shopping experience, Journal of Retailing and Consumer Services, 40, 48-59.

Ting, D. H., Fong Lim, S., Patanmacia, T. S., Low, C. G. and Ker, G. C. (2011), Dependency on smartphone and the impact on purchase behavior, Young Consumers, 12 (3), 193-203.

Toufani, S., Stanton, J. P., and Chikweche, T. (2017), The importance of aesthetics on customers' intentions to purchase smartphones, Marketing Intelligence \& Planning, 35 (3), 316-338.

Van De Ven, N., Zeelenberg, M. and Pieters, R. I. K. (2011), The Envy Premium in Product Evaluation, Journal of Consumer Research, 37 (6), 984-998.

van Lierop, D. and El-Geneidy, A. (2016), Enjoying loyalty: The relationship between service quality, customer satisfaction, and behavioral intentions in public transit, Research in Transportation Economics.

Vigneron, F. and Johnson, L. (1999), A Review and a Conceptual Framework of Prestige-Seeking Consumer Behaviour, Academy of marketing Science Review. 1, 1-15.

Vigneron, F. and Johnson, L. (2004), Measuring Perceptions of Brand Luxury, Brand management, 1 (6), 484-506.

Vonortas, N. S. (2018), International perspectives on innovation: introduction, The Journal of Technology Transfer, 43 (2), 259-262.

Weathington, B. L., Cunningham, C.J. and Pittenger, D.J. (2012), Understanding Business Research, New Jersey: John Wiley \& Sons Inc.

Wong, N.Y. and Ahuvia, A.C. (1998), Personal taste and family face: luxury consumption in Confucian and Western societies, Psychology \& Marketing, 15 (5), 423-441.

Wong, A., Chung, Y. and Zaichkowsky, J.L. (1999), Understanding luxury brands in Hong Kong, European Advances in Consumer Research, 4 (3), 310-316. 